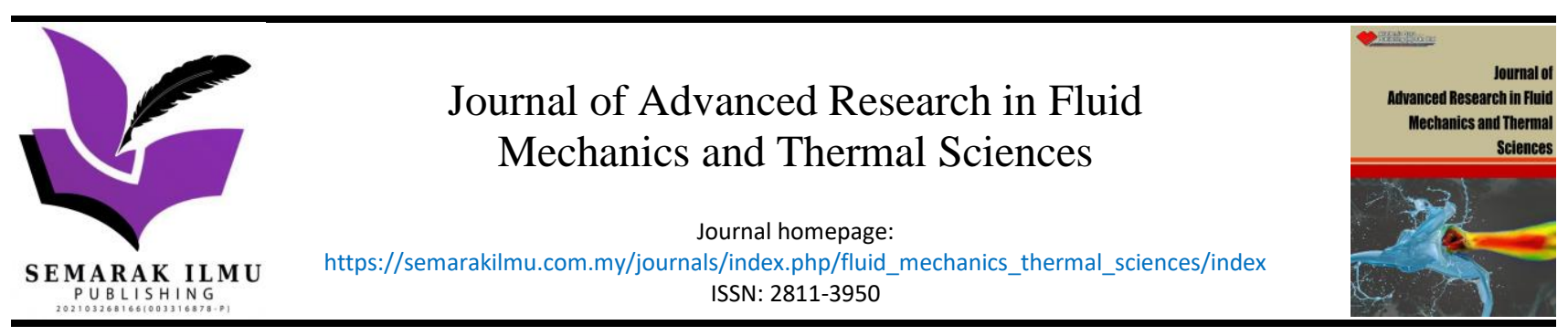

\title{
The Effect of Variation in Mass Flow Rate and Solar Irradiance on Temperature Uniformity and Thermal Performance of Photovoltaic Thermal: A Simulated CFD Study
}

\author{
Mohd Afzanizam Mohd Rosli ${ }^{1,2, *}$, Muhammad Zaid Nawam ${ }^{1}$, Irfan Alias Farhan Latif ${ }^{1}$, Safarudin \\ Ghazali Herawan ${ }^{3}$, Noriffah Md Noh ${ }^{1}$, Siti Nur Dini Noordin Saleem ${ }^{1}$, Faridah Hussain ${ }^{4}$

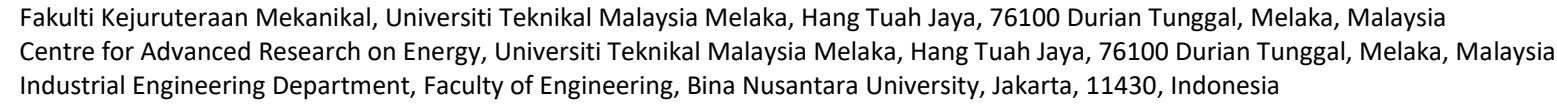

\section{ARTICLE INFO}

\section{Article history:}

Received 11 September 2021

Received in revised form 5 January 2022

Accepted 5 January 2022

Available online 26 January 2022

\section{Keywords:}

Photovoltaic Thermal; Temperature Distribution; Computational Fluid; Dynamics; Simulation; Mass Flow Rate; Solar Irradiation

\section{ABSTRACT}

Although, the effect of mass flow rate and solar irradiance variation is present in literature, it is still of significant interest to investigate the extent of the effect especially when utilizing a custom absorber design. In this paper, the effect of changing the mass flow rate and solar irradiance on the performance and temperature uniformity of a PVT using a custom spiral absorber design is simulated using ANSYS CFD software. By increasing the mass flow rate, the temperature uniformity and the performance parameters such as the average PV temperature, water outlet temperature, thermal and electrical efficiency all increase. By increasing the irradiance level, performance and temperature uniformity drop albeit at a smaller degree compared to change observed in mass flow rate variation. Amongst the tested range, the optimum mass flow rate and solar irradiance levels for best performance are $40 \mathrm{~kg} / \mathrm{h}$ and $800-1000 \mathrm{~W} / \mathrm{m}^{2}$, respectively.

\section{Introduction}

Due to the ever-increasing energy demand because of factors such as increasing population and rapid advancement of technology, renewable energy resources (solar energy, wind energy, hydro energy, biomass, geothermal energy etc.) are put in the spotlight to increase the energy supply [13]. In addition to that, energy production by conventional (non-renewable resources such as fossil fuels, natural gas, coal, etc.) means also contributes to global greenhouse gas emissions [3]. Besides, the consumption rate of non-renewable energy resources is high enough as it is today which has led to some depletion concerns in the future. Increasing the consumption rate will only make things worse. Therefore, relying on conventional non-renewable resources to meet the increased supplydemand is not feasible.

\footnotetext{
* Corresponding author.

E-mail address: afzanizam@utem.edu.my
}

https://doi.org/10.37934/arfmts.91.2.106119 
One of the renewable energy resources with substantial energy generation potential is solar energy [4]. Solar energy is available across the globe albeit at varying degrees of intensity. Solar photovoltaic (PV) cell systems are energy generators that utilize solar energy to produce electricity and thermal energy. Due to inefficient technology, it is still considered an expensive source of electrical energy generation. Most PV systems have an electrical efficiency in the range of $4-17 \%$ as a major portion of the solar energy utilized by the PV systems is converted into thermal energy instead [5]. This raises the operating temperature of the PV cells. The operating temperature of the PV cell has a direct correlation to energy generation. With an increase in the operating temperature, the efficiency of the PV cell electricity generation decreases [6-8]. Researchers have been hard at work, trying to improve the efficiency of PV systems. One of the most prominent approaches to improve the efficiency of PV cells is to minimize or take away the thermal energy generated by the PV cells away. This can be achieved by introducing a cooling component to the PV systems $[6,7,9-13]$. The modified system is known as the solar photovoltaic thermal (PVT) system. PVT system achieves this by extracting the heat from the PV panel into a working fluid flowing through an absorber. PVT systems can have different types of absorber or collector configurations such as parabolic trough, parabolic dish, linear Fresnel and flat plate collectors (FPC) [14-16]. The most common of these is the FPC configuration which is the configuration addressed in this study.

In addition to PV cell operating temperature, the efficiency of the PVT systems also depends on various factors such as PVT design, working fluid used, temperature distribution on the PV cell plate and operating conditions such as mass flow rate of the working fluid, incident solar irradiance, working fluid inlet temperature, ambient wind speed, ambient air temperature etc. [6,17]. Various studies have worked on improving the electrical efficiency of PVT systems by altering the PVT design components such as the PV cells, absorber type, and working fluid type etc.). For example, Cappelletti mentions that mono-crystalline PV cells have higher efficiency compared to poly-crystalline PV cells [18]. In terms of the working fluid, air is considered to be less efficient than water which itself is less efficient compared to various nanofluids [5,19-25]. In terms of absorber configurations, the most common absorbers are serpentine, parallel, spiral, cross-fined absorbers amongst which, the spiral absorber is found to be the most efficient [2,26-32]. It was also found out that the absorber configuration consisting of round tubes instead of square tubes were more efficient $[2,27]$. Even temperature distribution on the PV cell plate leads to better overall performance and protects from hotspots, preserving the intended lifetime of the PV cells $[6,33,34]$. The temperature uniformity is most influenced by tube spacing and the absorber type. Small tube spacing and spiral absorber configurations lead to better temperature uniformity and therefore, better performance $[33,35]$.

The effect of operating conditions on the performance of the PVT systems is also studied extensively [36]. It is observed that a higher mass flow rate of the working fluid, Lower inlet temperature, moderate solar irradiance, high wind speed, and lower ambient air temperature leads to better performance [5,37].

This paper is a continuation of previous work by Rosli et al., [38], where a new absorber design for solar PVT was suggested to improve efficiency and to achieve a more uniform temperature distribution. The performance and the temperature uniformity of the new PVT system are simulated and validated. In this paper, the effect of two operating conditions namely mass flow rate, and solar irradiance on the performance and temperature uniformity of the PVT system fashioning the custom spiral absorber design is investigated using the same computational fluid dynamics (CFD) simulation model used in the previous work [38]. The effect of mass flow rate and solar irradiance on the performance and temperature uniformity are well documented in literature. However, the new design has a unique pipe arrangement. Therefore, the extent of their influence has not been tested for the custom absorber design introduced in previous work [38]. 


\section{Methodology}

The simulation is carried out in ANSYS using the same model utilized in the previous study. The simulation model is verified with the experimental data taken from a study by Hosseinzadeh et al., [5]. The methodology is the same as in the study by Rosli et al., [38]. The custom absorber designed is shown in Figure 1. The custom absorber has an approximate pipe length of $12.85 \mathrm{~m}$. The collector pipe is made of copper which has an inner diameter of $0.01 \mathrm{~m}$ and an outer diameter of $0.012 \mathrm{~m}$. The material properties and PVT layer dimensions are shown in Table 1 and Table 2. More details can be seen in the study by Rosli et al., [38].

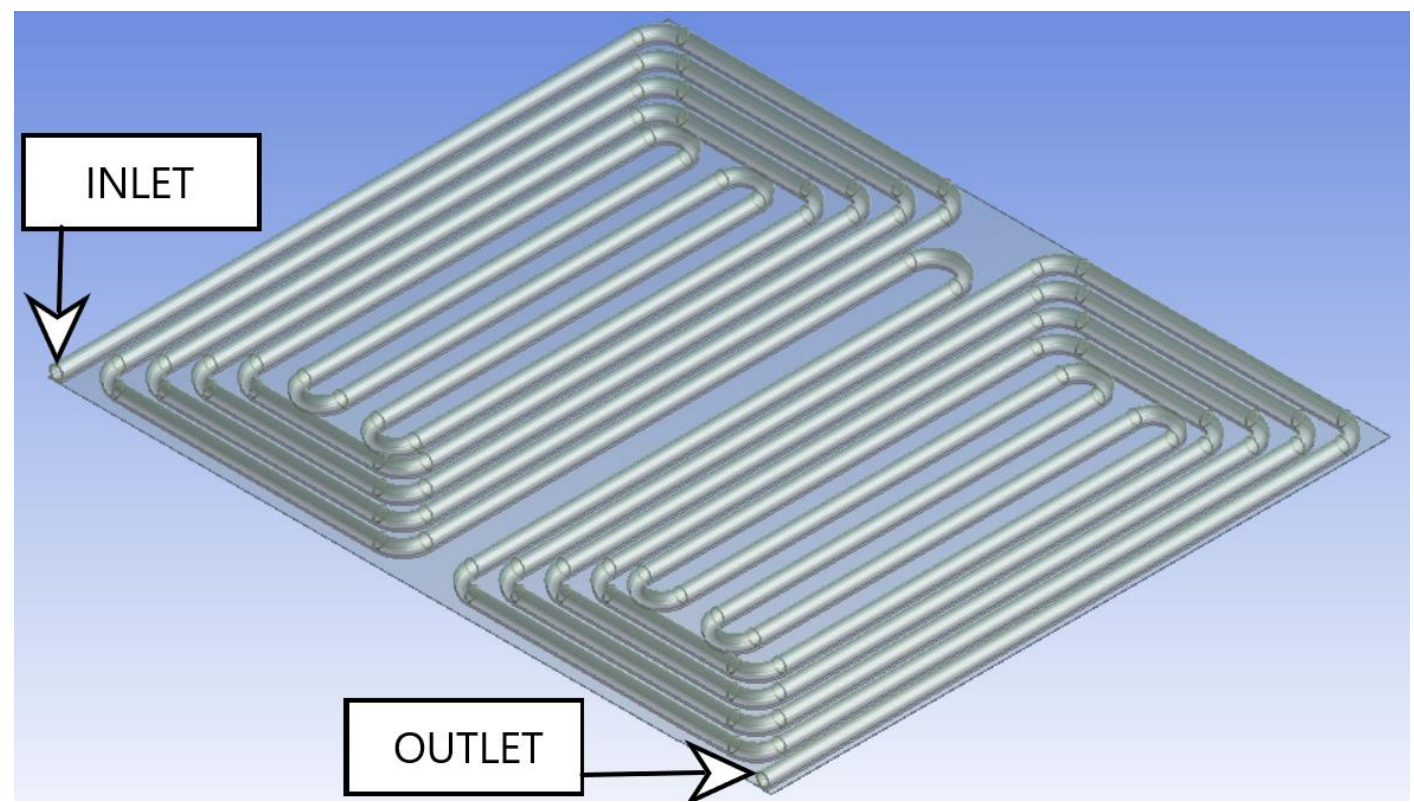

Fig. 1. The Custom Absorber Design [38]

Table 1

Material properties [38]

\begin{tabular}{|c|c|c|c|}
\hline Material & $\begin{array}{l}\text { Thermal Conductivity (k) } \\
\frac{W}{\boldsymbol{m}^{\mathbf{1}} \boldsymbol{K}^{\mathbf{1}}}\end{array}$ & $\begin{array}{l}\text { Specific Heat (Cp) } \\
\frac{\boldsymbol{J}}{\boldsymbol{K} \boldsymbol{g}^{\mathbf{1}} \boldsymbol{K}^{\mathbf{1}}}\end{array}$ & $\begin{array}{l}\text { Density } \\
\frac{\boldsymbol{K g}}{\boldsymbol{m}^{3}}\end{array}$ \\
\hline Glass & 1.3 & 749 & 2200 \\
\hline PV & 148 & 700 & 2330 \\
\hline Copper & 387.6 & 381 & 8978 \\
\hline Thermal Paste & 1 & 650 & 2400 \\
\hline Insulation & 0.173 & 700 & 2310 \\
\hline Water & 0.6 & 4182 & 998.2 \\
\hline
\end{tabular}

Table 2

PVT layer dimensions [38]

\begin{tabular}{ll}
\hline Layer & Dimensions $(\mathrm{L} \times \mathrm{W} \times \mathrm{H})$ \\
\hline Glass & $0.63 \mathrm{~m} \times 0.54 \mathrm{~m} \times 0.003 \mathrm{~m}$ \\
$\mathrm{PV}$ & $0.63 \mathrm{~m} \times 0.54 \mathrm{~m} \times 0.0003 \mathrm{~m}$ \\
Absorber Plate & $0.63 \mathrm{~m} \times 0.54 \mathrm{~m} \times 0.0004 \mathrm{~m}$ \\
Insulator & $0.63 \mathrm{~m} \times 0.54 \mathrm{~m} \times 0.013 \mathrm{~m}$ \\
\hline
\end{tabular}


The effect of mass flow rate and solar irradiance on the performance and the temperature uniformity of the PVT system is studied by observing key parameters such as the PV plate temperature, water outlet temperature, thermal efficiency and electrical efficiency at different mass flow rates and solar irradiance levels while keeping other operating parameters constant as shown in Table 3.

Table 3

Operating parameters

\begin{tabular}{ll}
\hline Parameter & Value \\
\hline Ambient Wind Speed $(\mathrm{m} / \mathrm{s})$ & 5 \\
Water Inlet Temperature $\left({ }^{\circ} \mathrm{C}\right)$ & 30 \\
Ambient Air Temperature $\left({ }^{\circ} \mathrm{C}\right)$ & 30 \\
\hline
\end{tabular}

When testing the effect of mass flow rate, the solar irradiance level is kept constant at $1000 \mathrm{~W} / \mathrm{m}^{2}$. The mass flow rate is changed at increments of $10 \mathrm{~kg} / \mathrm{h}$ from 10 to $40 \mathrm{~kg} / \mathrm{h}$ which is the laminar flow region. Conversely, when checking the solar irradiance, the mass flow rate is kept constant at $30 \mathrm{~kg} / \mathrm{h}$ while the irradiance levels vary from 600 to $1200 \mathrm{~W} / \mathrm{m}^{2}$ at $200 \mathrm{~W} / \mathrm{m}^{2}$ increments.

For temperature uniformity, the temperature readings at various points (the locations of which are shown in Figure 2) on top of the PV plate are taken and compared. The temperature along a line located at the centre of the top surface of the PV plate on the x-axis is also shown to observe temperature variation across the $\mathrm{x}$-axis.

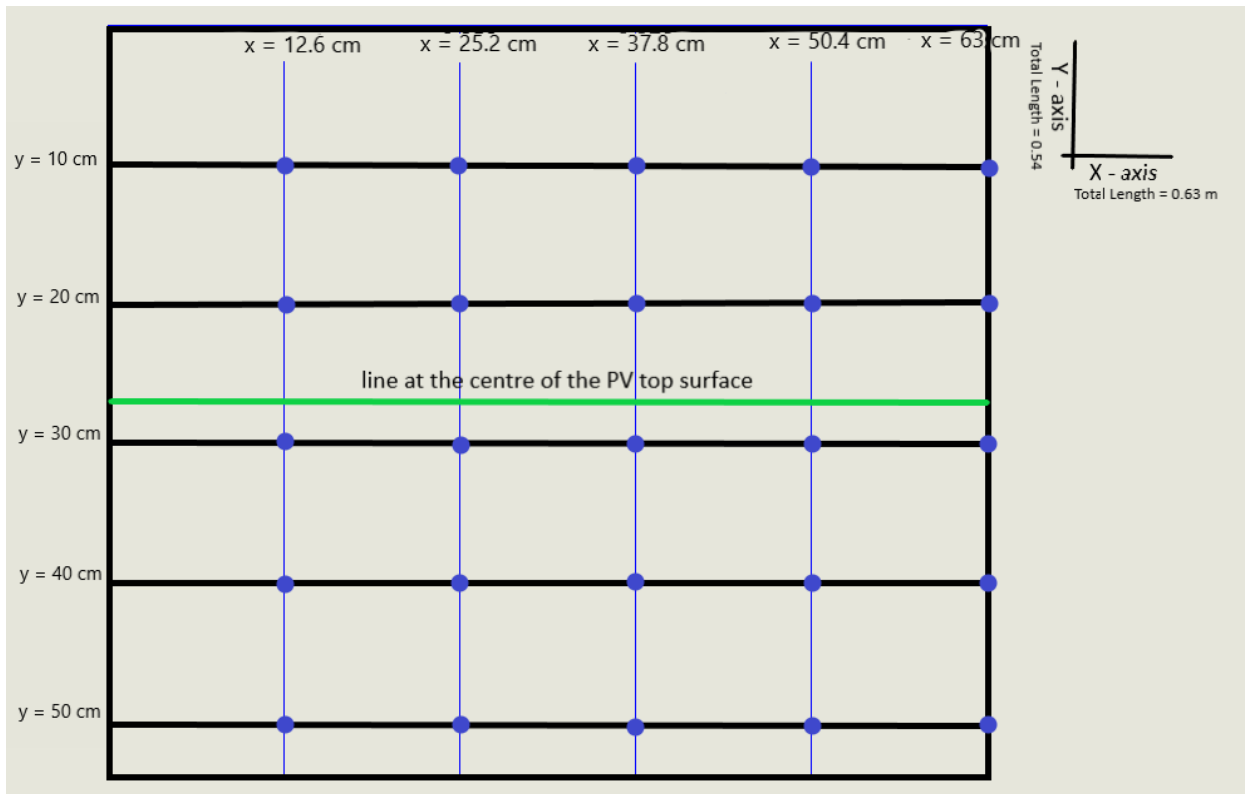

Fig. 2. Locations for temperature readings were taken to investigate temperature uniformity

\subsection{Model Discretization}

Computational fluid dynamics (CFD) is used to conduct the research. The following governing equations for continuity, momentum, and energy are employed when viewing the PVT system as a control volume [5,39]:

Continuity equation: $\quad \nabla \cdot\left(\rho_{f} V_{f}\right)=0$ 
Momentum equation: $\quad \nabla \cdot\left(\rho_{f} V_{f} V_{f}\right)=-\nabla P+\nabla \cdot\left(\mu_{f} \nabla V_{f}\right)$

Flow Energy equation: $\quad \nabla \cdot\left(V_{f} \rho_{f} C_{p, f} T_{f}\right)=\nabla \cdot\left(k_{f} \nabla T_{f}\right)$

Energy equation for solids: $\quad k_{s} \nabla\left(T_{S}\right)=0$

Where ' $V_{f}$ ' is the fluid velocity, and ' $P$ ' is pressure. Subscript ' $f$ ' indicates fluid, where ' $s$ ' indicates solid.

ANSYS is used to discretize the equations and solve them using the pressure-based finite volume approach. The SIMPLE technique is used to link pressure and velocity. Convective terms are interpolated using a second-order upwind method. The wall condition is present on the top of the glass surface, with a heat generation rate equal to the absorbed solar irradiation. The glass is expected to absorb about $10 \%$ of it, while the PV module absorbs the rest. Convection also happens in the surrounding air. It is projected that the ambient wind speed is less than $5 \mathrm{~m} / \mathrm{s}$. The following equation can be used to determine convective heat transfer [40]:

$h_{w}=5.7+3.8 V_{w} \quad$ for $V_{w}<5 \mathrm{~m} / \mathrm{s}$

Where ' $h h_{w}$ ' is the convective heat transfer co-efficient, and ' $V_{w}$ ' is the wind speed.

Taking the PVT system as a control volume and assuming steady-state conditions applied, the energy balance for the PVT system can be expressed as:

$E_{\text {sun }}+E_{\text {mass,in }}=E_{\text {el }}+E_{\text {mass,out }}+E_{\text {loss }}$

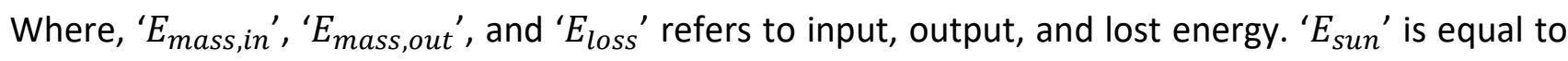
the absorbed solar irradiation, and it can be expressed as:

$E_{\text {sun }}=G \cdot A c \cdot \tau_{g} \cdot \alpha_{\text {cell }}$

' $G$ ' is the rate of total solar irradiation, ' $A c^{\prime}$ is the surface area of the collector, ' $\tau_{g}$ ' is the transmissivity of the glass cover, while ' $\alpha_{c e l l}$ ' is the absorptivity of the PV cells. The energy relating to mass flow is calculated as:

$E_{\text {mass }, \text { out }}-E_{\text {mass }, \text { in }}=E_{\text {th }}=m_{f} C_{p, f} \cdot\left(T_{f, \text { out }}-T_{f, \text { in }}\right)$

Where ' $m_{f}$ ' is the mass flow rate and ' $T_{f, \text { in' }}$ ' the fluid temperature. The thermal efficiency of the system is calculated by:

$\eta_{t h}=\frac{E_{t h}}{E_{\text {sun }}}=m_{f} C_{p, f} \cdot \frac{T_{f, o u t}-T_{f, \text { in }}}{G \cdot A c \cdot \tau_{g} \cdot \alpha_{\text {cell }}}$

The electrical energy efficiency of the PVT system is calculated from the equation [41]:

$\eta_{e l}=\frac{E_{e l}}{E_{\text {sun }}}=\eta_{r} \cdot\left[1-0.0045 \cdot\left(T_{\text {cell }}-298.15\right)\right]$ 
Where ' $\eta_{r}$ ' is the PV module efficiency, and ' $T_{c e l l}$ ' is the temperature of the PV cell. This equation is used for numerical analysis. For experimental analysis, the electrical energy efficiency of PVT system is found by [42]:

$\eta_{e l}=\frac{E_{e l}}{E_{\text {sun }}}=\frac{V_{o c} \cdot I_{s c} \cdot F F}{G \cdot A c \cdot \tau_{g} \cdot \alpha_{c e l l}}$

Where ' $V_{o c}$ ' and ' $I_{s c}$ ' stand for open-circuit voltage and short circuit current of the PV module, respectively. ' $F F$ ' is the fill factor, which is calculated by [43]:

$F F=\frac{V_{\max } \cdot I_{\max }}{V_{o c} \cdot I_{S c}}$

The overall efficiency is the sum of thermal efficiency and electrical efficiency. The heat transfer in the PVT system due to the incident solar irradiation is simulated by the heat flux method [44]. The temperature distribution uniformity is checked by plotting the temperature across a line in the middle of the PV module's top surface.

\section{Results}

\subsection{An Overview of Results from Previous Work}

For validation, the simulation model is used to replicate the experiment from the study by Hosseinzadeh et al., [5]. The PVT design was recreated and simulated in the model with the same boundary conditions. The average percentage error between the simulated and the experimental average PV temperature and water outlet temperature is found to be $7.8 \%$ and $6.67 \%$, respectively. Whereas the error for electrical efficiency and thermal efficiency between the simulation and the experimental data is $0.28 \%$ and $33.62 \%$, respectively. as the error is high, the results are compensated based on average error.

As demonstrated in Figure 3, meshing is done in ANSYS using polyhedral volume meshing. Mesh counts of $2.9 \mathrm{M}, 3.4 \mathrm{M}, 3.98 \mathrm{M}$, and $4.78 \mathrm{M}$ were used to test the mesh parameters. Table 4 shows the outcomes of the simulations utilising these various mesh counts.

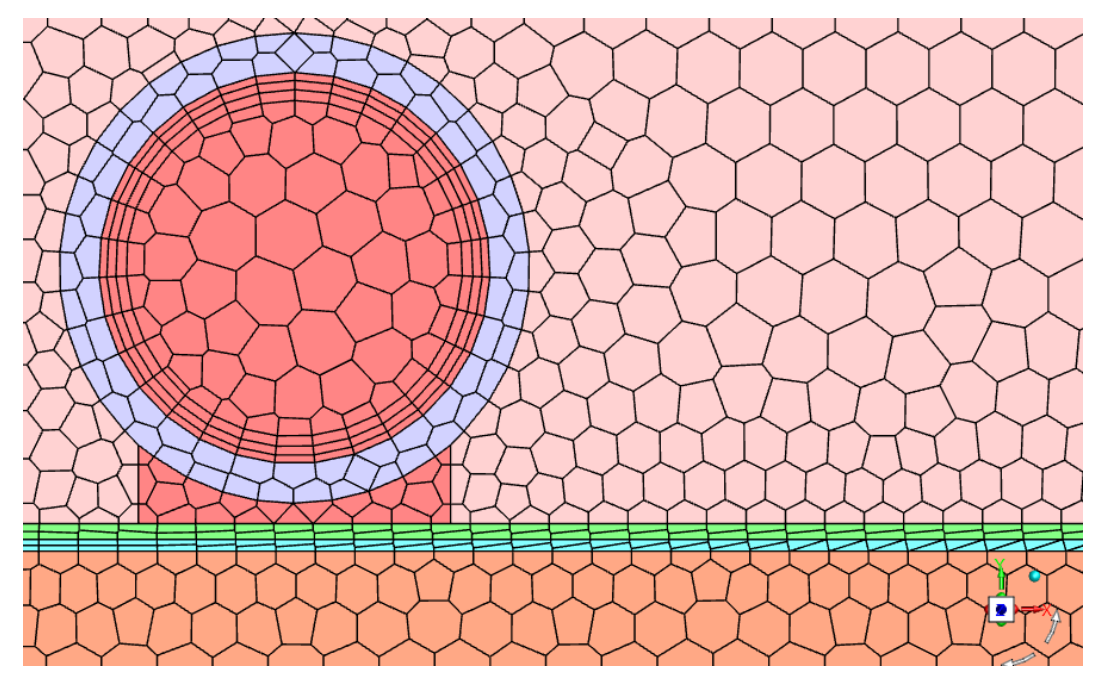

Fig. 3. A view of the mesh used for simulation [38] 
Table 4

Coolant outlet and PV temperature with respect to mesh size

\begin{tabular}{lll}
\hline Mesh Size in Million (M) & PV Temperature $\left({ }^{\circ} \mathrm{C}\right)$ & Outlet Temperature $\left({ }^{\circ} \mathrm{C}\right)$ \\
\hline 2.9 & 51.05 & 50.34 \\
3.4 & 51.07 & 50.35 \\
3.98 & 51.05 & 50.35 \\
4.78 & 51.03 & 50.35 \\
\hline
\end{tabular}

Despite the fact that the results vary with mesh size, due to hardware limitations and the small magnitude of change, the mesh size is not adjusted further to increase the mesh count. A minimum orthogonal quality of 0.2 , a maximum aspect ratio of 27 , and a maximum skewness of 0.78 are all features of the mesh.
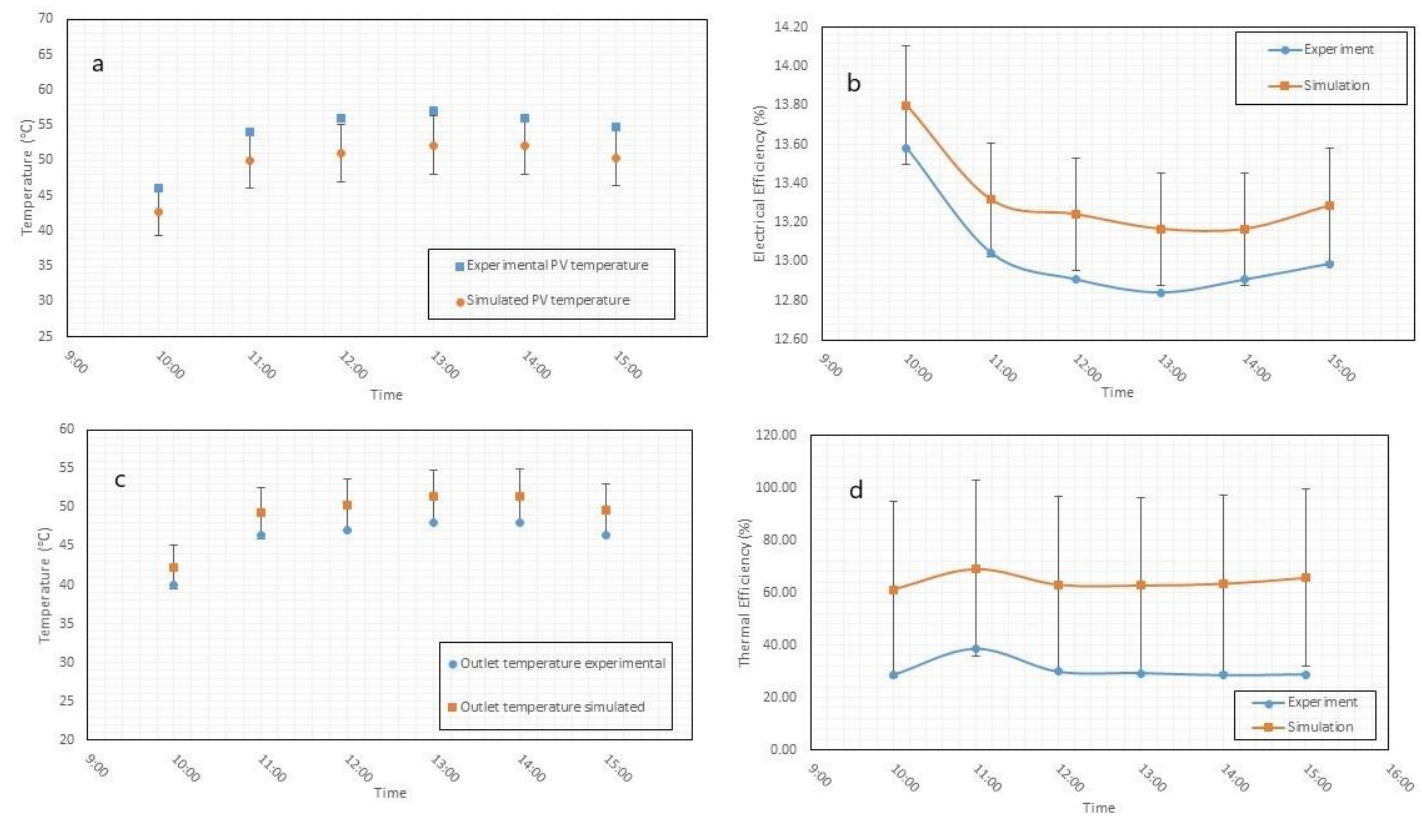

Fig. 4. (a) PV temperature error, (b) Electrical efficiency error, (c) Coolant outlet temperature error, (d) Thermal efficiency error [38]

After error compensation, the average thermal efficiency obtained for the custom absorber is $49.46 \%$ and the custom absorber has an average electrical efficiency of $13.87 \%$. The improved absorber design results in an average PV temperature of $37.63^{\circ} \mathrm{C}$ and a coolant outlet temperature of $38.11^{\circ} \mathrm{C}$. When evaluated under the same operating conditions, the bespoke absorber design improves the thermal and electrical efficiency of the PV by $3.21 \%$ and $0.65 \%$, respectively, over the serpentine absorber utilized in a study by Hosseinzadeh et al., [5].

In terms of temperature uniformity, the new absorber allowed better temperature distribution across the PV plate. Further details can be found in the previous paper by Rosli et al., [38]. It should be noted that the results presented in this study are without any error compensation, which is not needed here because the main focus is to check the effect of changing mass flow rate and solar irradiance on the performance. This can be studied by observing the trend even if the values are inaccurate. 


\subsection{Effect of Mass Flow Rate on Performance}

CFD simulations at various mass flow rates are used to determine efficiency and temperature distribution. The mass flow rates that were tested are $10,20,30$, and $40 \mathrm{~kg} / \mathrm{h}$. The incident sun irradiation is maintained at $1000 \mathrm{~W} / \mathrm{m}^{2}$.

In terms of performance, as shown in Table 5, a higher flow rate results in better performance. Both efficiency ratings are observed to be improving with an increase in mass flow rate.

Table 5

Temperature and efficiency of PVT at different mass flow rates

\begin{tabular}{lllll}
\hline $\begin{array}{l}\text { Mass Flow } \\
\text { Rate }(\mathrm{Kg} / \mathrm{h})\end{array}$ & $\begin{array}{l}\text { PV Temperature } \\
\left({ }^{\circ} \mathrm{C}\right)\end{array}$ & $\begin{array}{l}\text { Outlet } \\
\text { Temperature }\left({ }^{\circ} \mathrm{C}\right)\end{array}$ & $\begin{array}{l}\text { Thermal } \\
\text { Efficiency }(\%)\end{array}$ & $\begin{array}{l}\text { Electrical } \\
\text { Efficiency }(\%)\end{array}$ \\
\hline 10 & 45.43 & 49.04 & 64.99 & 13.62 \\
20 & 39.76 & 41.39 & 77.85 & 14.01 \\
30 & 37.63 & 38.11 & 83.07 & 14.15 \\
40 & 36.5 & 36.29 & 85.89 & 14.22 \\
\hline
\end{tabular}

\subsection{Effect of Mass Flow Rate on Temperature Uniformity}

It can be observed from Table 6 and Figure 5 that not only is the overall temperature decreased when increasing mass flow rate, the temperature uniformity is also improved. As a result, it stands to reason that a larger flow rate will result in not only improved performance due to lower temperatures, but also better temperature uniformity for the custom absorber.

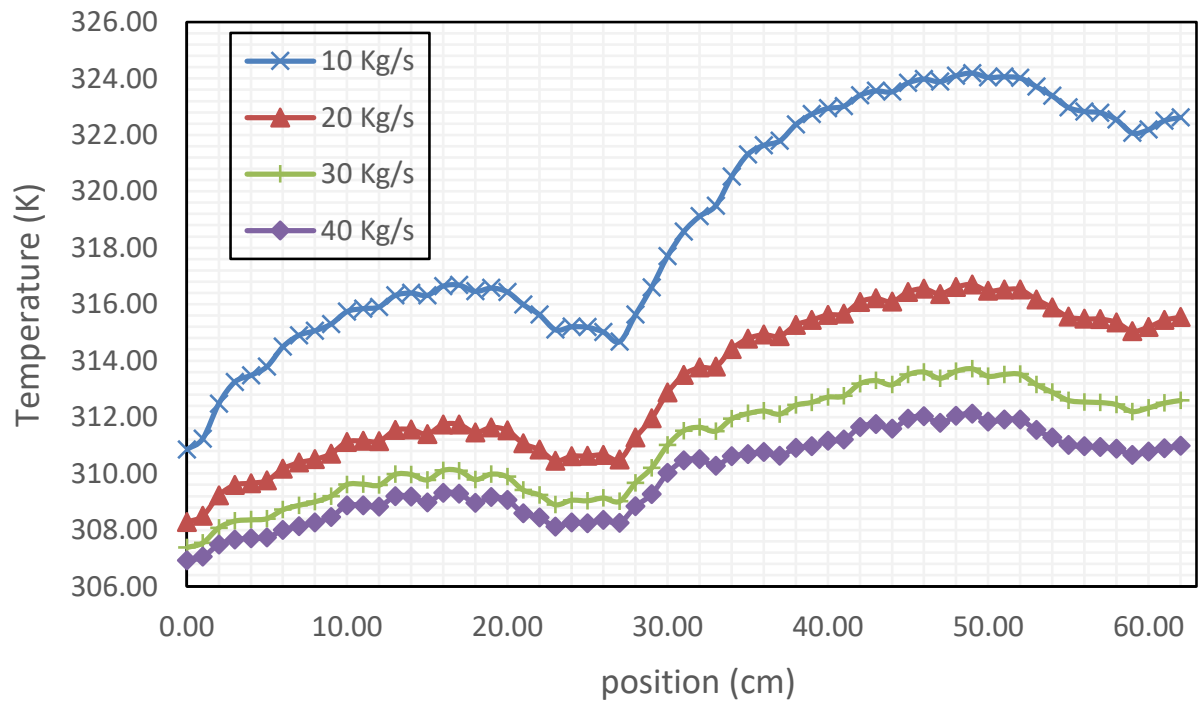

Fig. 5. Temperature distribution on a line at the centre of the PV top surface at different mass flow rates 
Table 6

The temperature at various points on the PV surface at different Mass Flow Rates

\begin{tabular}{|c|c|c|c|c|c|}
\hline \multicolumn{6}{|c|}{ Mass Flow Rate $=10 \mathrm{~kg} / \mathrm{h}$; Irradiance $=1000 \mathrm{~W} / \mathrm{m}^{2}$} \\
\hline Locations $(x, y) \mathrm{cm}$ & 12.6 & 25.2 & 37.8 & 50.4 & 63 \\
\hline \multicolumn{6}{|c|}{ Temperature $\left({ }^{\circ} \mathrm{C}\right)$} \\
\hline 10 & 37.07 & 42.32 & 45.46 & 50.26 & 49.17 \\
\hline 20 & 37.51 & 43.26 & 45.48 & 50.77 & 49.40 \\
\hline 30 & 37.78 & 43.36 & 45.38 & 50.78 & 49.49 \\
\hline 40 & 37.96 & 43.07 & 45.12 & 50.47 & 49.52 \\
\hline 50 & 37.44 & 40.74 & 46.42 & 49.22 & 49.79 \\
\hline \multicolumn{6}{|c|}{ Mass Flow Rate $=20 \mathrm{~kg} / \mathrm{h}$; Irradiance $=1000 \mathrm{~W} / \mathrm{m}^{2}$} \\
\hline \multirow[t]{2}{*}{ Locations $(x, y) \mathrm{cm}$} & 12.6 & 25.2 & 37.8 & 50.4 & 63 \\
\hline & \multicolumn{5}{|c|}{ Temperature $\left({ }^{\circ} \mathrm{C}\right)$} \\
\hline 10 & 34.76 & 37.49 & 40.31 & 42.72 & 42.21 \\
\hline 20 & 35.02 & 38.35 & 40.37 & 43.30 & 42.36 \\
\hline 30 & 35.16 & 38.45 & 40.32 & 43.31 & 42.40 \\
\hline 40 & 35.22 & 38.17 & 40.13 & 42.97 & 42.37 \\
\hline 50 & 34.96 & 36.63 & 41.78 & 41.98 & 42.62 \\
\hline \multicolumn{6}{|c|}{ Mass Flow Rate $=30 \mathrm{~kg} / \mathrm{h}$; Irradiance $=1000 \mathrm{~W} / \mathrm{m}^{2}$} \\
\hline \multirow[t]{2}{*}{ Locations $(x, y) \mathrm{cm}$} & 12.6 & 25.2 & 37.8 & 50.4 & 63 \\
\hline & \multicolumn{5}{|c|}{ Temperature $\left({ }^{\circ} \mathrm{C}\right)$} \\
\hline 10 & 33.95 & 35.93 & 38.31 & 39.73 & 39.30 \\
\hline 20 & 34.15 & 36.73 & 38.38 & 40.33 & 39.42 \\
\hline 30 & 34.25 & 36.83 & 38.35 & 40.34 & 39.44 \\
\hline 40 & 34.28 & 36.56 & 38.19 & 40.00 & 39.38 \\
\hline 50 & 34.14 & 35.23 & 39.97 & 39.07 & 39.60 \\
\hline \multicolumn{6}{|c|}{ Mass Flow Rate $=40 \mathrm{~kg} / \mathrm{h} ;$ Irradiance $=1000 \mathrm{~W} / \mathrm{m}^{2}$} \\
\hline \multirow[t]{2}{*}{ Locations $(x, y) \mathrm{cm}$} & 12.6 & 25.2 & 37.8 & 50.4 & 63 \\
\hline & \multicolumn{5}{|c|}{ Temperature $\left({ }^{\circ} \mathrm{C}\right)$} \\
\hline 10 & 33.53 & 35.17 & 37.25 & 38.15 & 37.72 \\
\hline 20 & 33.71 & 35.94 & 37.31 & 38.75 & 37.81 \\
\hline 30 & 33.79 & 36.03 & 37.29 & 38.76 & 37.82 \\
\hline 40 & 33.80 & 35.78 & 37.16 & 38.44 & 37.75 \\
\hline 50 & 33.73 & 34.53 & 39.01 & 37.51 & 37.95 \\
\hline
\end{tabular}

\subsection{Effect of Solar Irradiance on Performance}

CFD simulations at various levels of solar irradiation are used to determine efficiency and temperature distribution. $600,800,1000$, and $1200 \mathrm{~W} / \mathrm{m}^{2}$ were the tested levels. The mass flow rate is kept constant at $30 \mathrm{~kg} / \mathrm{h}$ in this case. Lowering solar irradiation results in higher electrical efficiency since less thermal energy is created, as evident from the data in Table 7. But lower irradiance also leads to low power generation. Whereas thermal efficiency is influenced significantly by solar irradiation.

\section{Table 7}

Temperature and efficiency of PVT at different irradiance levels

\begin{tabular}{lllll}
\hline $\begin{array}{l}\text { Solar Irradiance } \\
\left(\boldsymbol{W} / \boldsymbol{m}^{2}\right)\end{array}$ & $\begin{array}{l}\text { PV Temperature } \\
\left({ }^{\circ} \mathrm{C}\right)\end{array}$ & $\begin{array}{l}\text { Outlet } \\
\text { Temperature }\left({ }^{\circ} \mathrm{C}\right)\end{array}$ & $\begin{array}{l}\text { Thermal } \\
\text { Efficiency (\%) }\end{array}$ & $\begin{array}{l}\text { Electrical } \\
\text { Efficiency }(\%)\end{array}$ \\
\hline 600 & 34.58 & 34.86 & 83.04 & 14.35 \\
800 & 36.10 & 36.49 & 83.05 & 14.25 \\
1000 & 37.63 & 38.11 & 83.07 & 14.15 \\
1200 & 39.15 & 39.73 & 83.05 & 14.04 \\
\hline
\end{tabular}




\subsection{Effect of Solar Irradiance on Temperature Uniformity}

In terms of temperature distribution, as shown in Figure 6 and Table 8, the irradiance level has a small impact on the temperature distribution across the PV. Lower irradiance levels, on the other hand, produce a little better temperature distribution accompanied by lower overall PV temperatures.

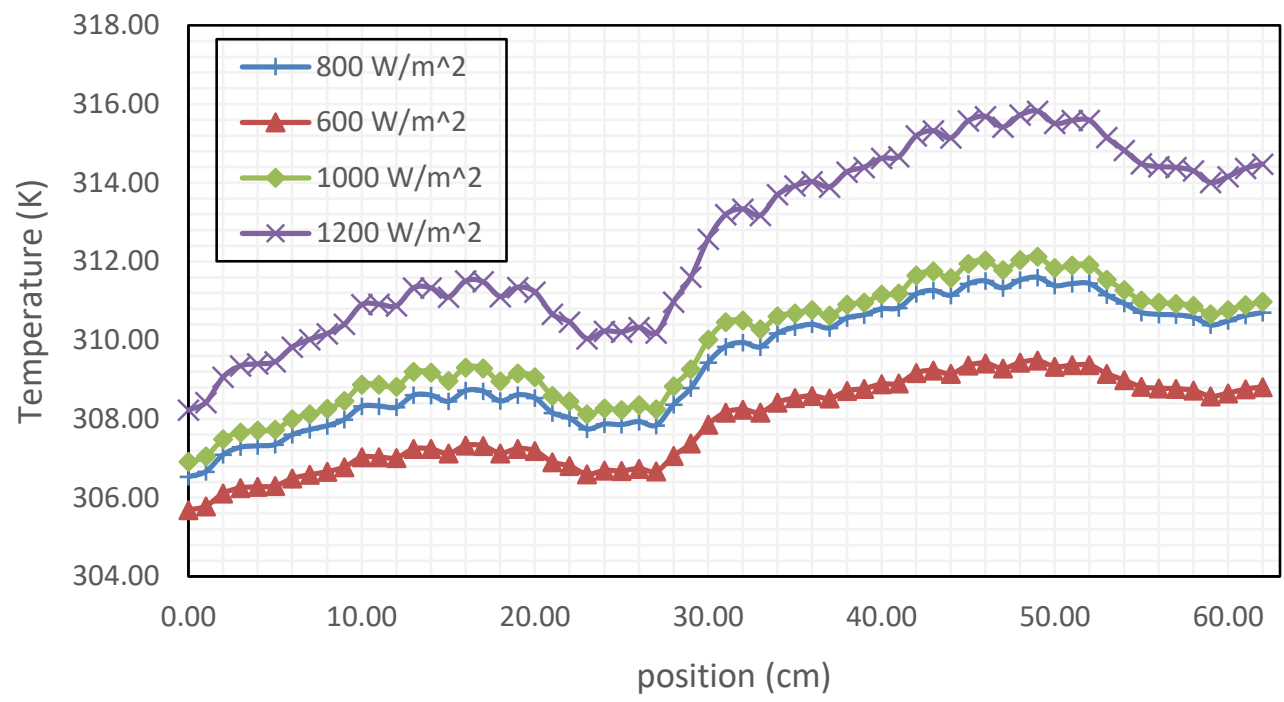

Fig. 6. Temperature distribution on a line at the centre of the PV top surface at different solar irradiance levels

\section{Table 8}

The temperature at various points on the PV surface at different irradiance levels

\begin{tabular}{|c|c|c|c|c|c|}
\hline \multicolumn{6}{|c|}{ Irradiance $=600 \mathrm{~W} / \mathrm{m}^{2} ;$ Mass Flow Rate $=30 \mathrm{~kg} / \mathrm{h}$} \\
\hline Locations $(x, y) \mathrm{cm}$ & 12.6 & 25.2 & 37.8 & 50.4 & 63 \\
\hline \multicolumn{6}{|c|}{ Temperature $\left({ }^{\circ} \mathrm{C}\right)$} \\
\hline 10 & 32.37 & 33.56 & 34.99 & 35.84 & 35.58 \\
\hline 20 & 32.49 & 34.04 & 35.03 & 36.20 & 35.65 \\
\hline 30 & 32.55 & 34.10 & 35.01 & 36.20 & 35.66 \\
\hline 40 & 32.57 & 33.94 & 34.91 & 36.00 & 35.63 \\
\hline 50 & 32.48 & 33.14 & 35.98 & 35.44 & 35.76 \\
\hline \multicolumn{6}{|c|}{ Irradiance $=800 \boldsymbol{W} / \boldsymbol{m}^{2} ;$ Mass Flow Rate $=30 \mathrm{~kg} / \mathrm{h}$} \\
\hline \multirow[t]{2}{*}{ Locations $(x, y) \mathrm{cm}$} & 12.6 & 25.2 & 37.8 & 50.4 & 63 \\
\hline & \multicolumn{5}{|c|}{ Temperature $\left({ }^{\circ} \mathrm{C}\right)$} \\
\hline 10 & 33.16 & 34.74 & 36.65 & 37.78 & 37.44 \\
\hline 20 & 33.32 & 35.38 & 36.70 & 38.26 & 37.53 \\
\hline 30 & 33.40 & 35.46 & 36.68 & 38.27 & 37.55 \\
\hline 40 & 33.43 & 35.25 & 36.55 & 38.00 & 37.51 \\
\hline 50 & 33.31 & 34.18 & 37.98 & 37.25 & 37.68 \\
\hline \multicolumn{6}{|c|}{ Irradiance $=1000 \boldsymbol{W} / \boldsymbol{m}^{2} ;$ Mass Flow Rate $=30 \mathrm{~kg} / \mathrm{h}$} \\
\hline \multirow[t]{2}{*}{ Locations $(\mathrm{x}, \mathrm{y}) \mathrm{cm}$} & 12.6 & 25.2 & 37.8 & 50.4 & 63 \\
\hline & \multicolumn{5}{|c|}{ Temperature $\left({ }^{\circ} \mathrm{C}\right)$} \\
\hline 10 & 33.95 & 35.93 & 38.31 & 39.73 & 39.30 \\
\hline 20 & 34.15 & 36.73 & 38.38 & 40.33 & 39.42 \\
\hline 30 & 34.25 & 36.83 & 38.35 & 40.34 & 39.44 \\
\hline 40 & 34.28 & 36.56 & 38.19 & 40.00 & 39.38 \\
\hline 50 & 34.14 & 35.23 & 39.97 & 39.07 & 39.60 \\
\hline
\end{tabular}




\begin{tabular}{|c|c|c|c|c|c|}
\hline \multicolumn{6}{|c|}{ Irradiance $=1200 \mathrm{~W} / \mathrm{m}^{2} ;$ Mass Flow Rate $=30 \mathrm{~kg} / \mathrm{h}$} \\
\hline Locations $(x, y) \mathrm{cm}$ & 12.6 & 25.2 & 37.8 & 50.4 & 63 \\
\hline \multicolumn{6}{|c|}{ Temperature $\left({ }^{\circ} \mathrm{C}\right)$} \\
\hline 10 & 34.74 & 37.11 & 39.97 & 41.68 & 41.17 \\
\hline 20 & 34.98 & 38.08 & 40.05 & 42.39 & 41.30 \\
\hline 30 & 35.10 & 38.20 & 40.02 & 42.41 & 41.32 \\
\hline 40 & 35.14 & 37.88 & 39.83 & 42.00 & 41.26 \\
\hline 50 & 34.97 & 36.27 & 41.96 & 40.88 & 41.52 \\
\hline
\end{tabular}

\subsection{Discussion}

Regarding performance, it was found that when the mass flow rate was increased from $10 \mathrm{~kg} / \mathrm{h}$ to $40 \mathrm{~kg} / \mathrm{h}$, the average PV plate temperature dropped by a difference of $8.93^{\circ} \mathrm{C}$ from $45.43^{\circ} \mathrm{C}$ to $36.5^{\circ} \mathrm{C}$. the most significant drop was observed in change from $10 \mathrm{~kg} / \mathrm{h}$ to $20 \mathrm{~kg} / \mathrm{h}$ while the subsequent temperature drops were relatively smaller. Therefore, it can be estimated that in the laminar flow regime, the degree of the temperature drop gets smaller when reaching the laminar region. A similar trend was observed for the outlet temperature of the working fluid. The thermal efficiency increased with an increase in flow rate with a similar trend as well from $64.99 \%$ at $10 \mathrm{~kg} / \mathrm{h}$ to $85.89 \%$ at $40 \mathrm{~kg} / \mathrm{h}$. The electrical efficiency change in magnitude was the least in magnitude from $13.62 \%$ to $14.22 \%$ (by $0.6 \%$ ). regardless of the magnitude, the upgrade is still significant. By observing the trends, it can be estimated that an increase in flow rate will generally lead to better performance.

When changing the solar irradiance, the opposite trend was observed. The average PV plate temperature increased from $34.58^{\circ} \mathrm{C}$ to $39.15^{\circ} \mathrm{C}$ when changing the irradiance level from 600 to 1200 $\mathrm{W} / \mathrm{m}^{2}$, where the outlet temperature increased from $34.86^{\circ} \mathrm{C}$ to $39.73^{\circ} \mathrm{C}$. that's an increase of $4.57^{\circ} \mathrm{C}$ and $4.87^{\circ} \mathrm{C}$, respectively. No significant change in thermal efficiency was observed. However, the electrical efficiency dropped from $14.35 \%$ to $14.04 \%$. it should be noted that the magnitude of change is not as significant as that of the mass flow rate for solar irradiance. Since lower irradiance levels will provide less power, it will be more preferable to ignore this drop in performance and try to attain moderate solar irradiance levels. Even though the irradiance level is not a controllable parameter, it is still important to study its effect on performance so that the other operating conditions can be calibrated accordingly to obtain the best performance.

As we already found out, a high mass flow rate leads to Better Performance. The same can be said regarding temperature uniformity as can be seen from Figure 3 and Table 3 . The point-to-point temperature variation gets lower as the mass flow rate is increased. At mass flow rate of $10 \mathrm{~kg} / \mathrm{h}$, the temperature variation from $(0.126 \mathrm{~m}, 0.1 \mathrm{~m})$ to $(0.63 \mathrm{~m}, 0.1 \mathrm{~m})$ is $12.1^{\circ} \mathrm{C}$. However, at $40 \mathrm{~kg} / \mathrm{h}$, this variation changes to $4.19^{\circ} \mathrm{C}$. Therefore, it can be said that increasing the mass flow rate leads to better temperature distribution from cell to cell on a PV plate.

When changing the solar irradiance from 600 to $1200 \mathrm{~W} / \mathrm{m}^{2}$, the temperature variation from $(0.126 \mathrm{~m}, 0.1 \mathrm{~m})$ to $(0.63 \mathrm{~m}, 0.1 \mathrm{~m})$ changes from $3.21^{\circ} \mathrm{C}$ at $600 \mathrm{~W} / \mathrm{m}^{2}$ to $5.35^{\circ} \mathrm{C}$ at $1200 \mathrm{~W} / \mathrm{m}^{2}$. Similar to the effect on performance, the effect on temperature uniformity is there when changing the solar irradiance levels, however, it is not as significant as that of mass flow rate variation. The variation was observed to be the least when changing from $800 \mathrm{~W} / \mathrm{m}^{2}$ to $1200 \mathrm{~W} / \mathrm{m}^{2}$. This range can be given as a nice middle ground.

\section{Conclusion}

In this study, variation in performance and temperature uniformity at different mass flow rates and solar irradiance levels was simulated for a PVT using a custom spiral absorber design. It was found 
that increasing the mass flow rate increases the performance and the temperature distribution on the PV plate. On the other hand, increasing the solar irradiance level led to drops in performance and temperature distribution. It should be noted that the effect of changing the mass flow rate was far more significant compared to that of changing the irradiance level. It can be reasoned that the added benefit of potentially producing more power at higher irradiance levels with optimum operating parameters outweighs the drop in performance observed.

For the PVT system using the custom spiral absorber design, a mass flow rate of $40 \mathrm{~kg} / \mathrm{h}$ and an irradiance level between $800 \mathrm{~W} / \mathrm{m}^{2}$ and $1000 \mathrm{~W} / \mathrm{m}^{2}$ can be deemed as the optimum parameter values for best performance and temperature uniformity.

\section{Acknowledgement}

The author appreciates the facilities and equipment provided by the Faculty of Mechanical Engineering and Centre of Advanced Research on Energy (CARe), Applied Solar Energy Laboratory (ASEL), and Universiti Teknikal Malaysia Melaka (UTeM) to support this research. This research was supported by the Malaysian Ministry of Higher Education under the grant FRGS/2018/FKMCARe/F00368.

\section{References}

[1] Ahmad, Tanveer, and Dongdong Zhang. "A critical review of comparative global historical energy consumption and future demand: The story told so far." Energy Reports 6 (2020): $1973-1991$. https://doi.org/10.1016/j.egyr.2020.07.020

[2] Sardouei, Masoud Mohammadi, Hamid Mortezapour, and Kazem Jafari Naeimi. "Temperature distribution and efficiency assessment of different PVT water collector designs." Sādhanā 43, no. 6 (2018): 1-13. https://doi.org/10.1007/s12046-018-0826-x

[3] Mbungu, Nsilulu T., Raj M. Naidoo, Ramesh C. Bansal, Mukwanga W. Siti, and Diambomba H. Tungadio. "An overview of renewable energy resources and grid integration for commercial building applications." Journal of Energy Storage 29 (2020): 101385. https://doi.org/10.1016/i.est.2020.101385

[4] Walmsley, Timothy G., Michael RW Walmsley, Petar S. Varbanov, and Jiří J. Klemeš. "Energy Ratio analysis and accounting for renewable and non-renewable electricity generation: A review." Renewable and Sustainable Energy Reviews 98 (2018): 328-345. https://doi.org/10.1016/i.rser.2018.09.034

[5] Hosseinzadeh, Mohammad, Ali Salari, Mohammad Sardarabadi, and Mohammad Passandideh-Fard. "Optimization and parametric analysis of a nanofluid based photovoltaic thermal system: 3D numerical model with experimental validation." Energy Conversion and Management $160 \quad$ (2018): https://doi.org/10.1016/i.enconman.2018.01.006

[6] Bahaidarah, Haitham M. S., Ahmer A. B. Baloch, and Palanichamy Gandhidasan. "Uniform cooling of photovoltaic panels: A review." Renewable and Sustainable Energy Reviews 57 (2016): 1520-1544. https://doi.org/10.1016/i.rser.2015.12.064

[7] Tuncel, B., T. Ozden, R. S. Balog, and B. G. Akinoglu. "Dynamic thermal modelling of PV performance and effect of heat capacity on the module temperature." Case Studies in Thermal Engineering 22 (2020): 100754. https://doi.org/10.1016/i.csite.2020.100754

[8] Abdullah, Amira Lateef, Suhaimi Misha, Noreffendy Tamaldin, Mohd Afzanizam Mohd Rosli, and Fadhil Abdulameer Sachit. "Hybrid Photovoltaic Thermal PVT Solar Systems Simulation via Simulink/Matlab." CFD Letters 11, no. 4 (2019): 64-78.

[9] Al-Waeli, Ali H., K. Sopian, Hussein A. Kazem, and Miqdam T. Chaichan. "Photovoltaic Solar Thermal (PV/T) Collectors Past, Present and Future: A." International Journal of Applied Engineering Research 11, no. 22 (2016): 10757-10765.

[10] Khelifa, A., K. Touafek, H. Ben Moussa, and I. Tabet. "Modeling and detailed study of hybrid photovoltaic thermal (PV/T) solar collector." Solar Energy 135 (2016): 169-176. https://doi.org/10.1016/i.solener.2016.05.048

[11] Abdullah, Amira Lateef, Suhaimi Misha, Noreffendy Tamaldin, Mohd Afzanizam Mohd Rosli, and Fadhil Abdulameer Sachit. "Technology Progress on Photovoltaic Thermal (PVT) Systems with Flat-Plate Water Collector Designs: A Review." Journal of Advanced Research in Fluid Mechanics and Thermal Sciences 59, no. 1 (2019): 107-141.

[12] Abdullah, Amira Lateef, Suhaimi Misha, Noreffendy Tamaldin, Mohd Afzanizam Mohd Rosli, and Fadhil Abdulameer Sachit. "Thermal Efficiency and Heat Removal Factor for Hybrid Photovoltaic Thermal PVT System." Journal of 
Advanced Research in Fluid Mechanics and Thermal Sciences 58, no. 1 (2019): 51-61.

[13] Sopian, Kamaruzzaman, Ali H. A. Alwaeli, Husam Abdulrasool Hasan, and Ali Najah Al-Shamani. "Advances in high efficiency photovoltaic thermal solar collectors." Journal of Advanced Research in Fluid Mechanics and Thermal Sciences 47, no. 1 (2018): 1-7.

[14] Ghasemi, Seyed Ebrahim, and Ali Akbar Ranjbar. "Thermal performance analysis of solar parabolic trough collector using nanofluid as working fluid: a CFD modelling study." Journal of Molecular Liquids 222 (2016): 159-166. https://doi.org/10.1016/i.molliq.2016.06.091

[15] Salam, Rahmat Awaludin, Muhammad Miftahul Munir, Thariq Warsahemas, Casmika Saputra, Hamzah Latief, and Khairurrijal Khairurrijal. "A simple solar simulator with highly stable controlled irradiance for solar panel characterization." Measurement and Control 52, no. 3-4 (2019): $159-168$. https://doi.org/10.1177/0020294019827327

[16] Mohd Rosli, Mohd Afzanizam, Sohif Mat, Kamaruzzaman Sopian, Mohd Yusof Sulaiman, Elias Ilias Salleh, and Mohd Khairul Anuar Sharif. "Thermal performance on unglazed photovoltaic thermal polymer collector." In Advanced Materials Research, vol. 911, pp. 238-242. Trans Tech Publications Ltd, 2014. https://doi.org/10.4028/www.scientific.net/AMR.911.238

[17] Atsu, Divine, and Alok Dhaundiyal. "Effect of ambient parameters on the temperature distribution of photovoltaic (PV) modules." Resources 8, no. 2 (2019): 107. https://doi.org/10.3390/resources8020107

[18] Cappelletti, Alessandro, Marcantonio Catelani, Lorenzo Ciani, Marian K. Kazimierczuk, and Alberto Reatti. "Practical Issues and Characterization of a Photovoltaic/Thermal Linear Focus 20x Solar Concentrator." IEEE Transactions on Instrumentation and Measurement 65, no. 11 (2016): 2464-2475. https://doi.org/10.1109/TIM.2016.2588638

[19] Syafiqah, Z., N. A. M. Amin, Y. M. Irwan, M. S. A. Majid, and N. A. Aziz. "Simulation study of air and water cooled photovoltaic panel using ANSYS." In Journal of Physics: Conference Series, vol. 908, no. 1, p. 012074. IOP Publishing, 2017. https://doi.org/10.1088/1742-6596/908/1/012074

[20] Ahmed, Asmaa, Hasan Baig, Senthilarasu Sundaram, and Tapas K. Mallick. "Use of nanofluids in solar PV/thermal systems." International Journal of Photoenergy 2019 (2019). https://doi.org/10.1155/2019/8039129

[21] Naghdbishi, Ali, Mohammad Eftekhari Yazdi, and Ghasem Akbari. "Experimental investigation of the effect of multiwall carbon nanotube-Water/glycol based nanofluids on a PVT system integrated with PCM-covered collector." Applied Thermal Engineering 178 (2020): 115556. https://doi.org/10.1016/i.applthermaleng.2020.115556

[22] Hissouf, Mohamed, Monssif Najim, and Adil Charef. "Numerical study of a covered Photovoltaic-Thermal Collector (PVT) enhancement using nanofluids." Solar Energy $199 \quad$ (2020): 115-127. https://doi.org/10.1016/j.solener.2020.01.083

[23] Fudholi, Ahmad, Nur Farhana Mohd Razali, Mohammad H. Yazdi, Adnan Ibrahim, Mohd Hafidz Ruslan, Mohd Yusof Othman, and Kamaruzzaman Sopian. "TiO 2 /water-based photovoltaic thermal (PVT) collector: Novel theoretical approach." Energy 183 (2019): 305-314. https://doi.org/10.1016/i.energy.2019.06.143

[24] Sachit, F. A., M. A. M. Rosli, N. Tamaldin, S. Misha, and A. L. Abdullah. "Nanofluids used in photovoltaic thermal (PV/T) systems." International Journal of Engineering \& Technology 7, no. 3.20 (2018): 599-611.

[25] Fudholi, Ahmad, Nur Farhana Mohd Razali, Mohd Hafidz Ruslan, and Kamaruzzaman Sopian. "Application of Nanofluids for Photovoltaic Thermal (PVT) Collectors: A Review." Journal of Advanced Research in Fluid Mechanics and Thermal Sciences 74, no. 1 (2020): 35-44. https://doi.org/10.37934/arfmts.74.1.3544

[26] Misha, S., Amira Lateef Abdullah, N. Tamaldin, M. A. M. Rosli, and F. A. Sachit. "Simulation CFD and experimental investigation of PVT water system under natural Malaysian weather conditions." Energy Reports 6 (2020): 28-44. https://doi.org/10.1016/i.egyr.2019.11.162

[27] Poredoš, Primož, Urban Tomc, Nada Petelin, Boris Vidrih, Uroš Flisar, and Andrej Kitanovski. "Numerical and experimental investigation of the energy and exergy performance of solar thermal, photovoltaic and photovoltaicthermal modules based on roll-bond heat exchangers." Energy Conversion and Management 210 (2020): 112674. https://doi.org/10.1016/i.enconman.2020.112674

[28] Kazem, Hussein A., Ali HA Al-Waeli, Miqdam T. Chaichan, Karrar H. Al-Waeli, Anwer Basim Al-Aasam, and K. Sopian. "Evaluation and comparison of different flow configurations PVT systems in Oman: A numerical and experimental investigation." Solar Energy 208 (2020): 58-88. https://doi.org/10.1016/i.solener.2020.07.078

[29] Madu, Kingsley, and A. E. Uyaelumuo. "Water Based Photovoltaic Thermal (PVT) Collector with Spiral Flow Absorber: An Energy and Exergy Evaluation." Equatorial Journal of Engineering 2018 (2018): 51-58.

[30] Ibrahim, Adnan, Ahmad Fudholi, Kamaruzzaman Sopian, Mohd Yusof Othman, and Mohd Hafidz Ruslan. "Efficiencies and improvement potential of building integrated photovoltaic thermal (BIPVT) system." Energy Conversion and Management 77 (2014): 527-534. https://doi.org/10.1016/j.enconman.2013.10.033

[31] Rosli, Mohd Afzanizam Mohd, Yap Joon Ping, Suhaimi Misha, Mohd Zaid Akop, Kamaruzzaman Sopian, Sohif Mat, Ali Najah Al-Shamani, and Muhammad Asraf Saruni. "Simulation study of computational fluid dynamics on photovoltaic thermal water collector with different designs of absorber tube." Journal of Advanced Research in 
Fluid Mechanics and Thermal Sciences 52, no. 1 (2018): 12-22.

[32] Razali, Nur Farhana Mohd, Ahmad Fudholi, Mohd Hafidz Ruslan, and Kamaruzzaman Sopian. "Improvement of photovoltaic module efficiency using spiral absorber and water." Journal of Advanced Research in Fluid Mechanics and Thermal Sciences 73, no. 1 (2020): 131-139. https://doi.org/10.37934/arfmts.73.1.131139

[33] Zhou, Jicheng, Haoyun Ke, and Xiaoqing Deng. "Experimental and CFD investigation on temperature distribution of a serpentine tube type photovoltaic/thermal collector." Solar Energy 174 (2018): 735-742. https://doi.org/10.1016/i.solener.2018.09.063

[34] Mohammed, Humaid, Manish Kumar, and Rajesh Gupta. "Bypass diode effect on temperature distribution in crystalline silicon photovoltaic module under partial shading." Solar Energy 208 (2020): 182-194. https://doi.org/10.1016/i.solener.2020.07.087

[35] Sachit, F. A., Noreffendy Tamaldin, M. A. M. Rosli, S. Misha, and A. L. Abdullah. "Current progress on flat-plate water collector design in photovoltaic thermal (PV/T) systems: A Review." Journal of Advanced Research in Dynamical and Control Systems 10, no. 4 (2018): 680-694.

[36] Abdullah, Amira Lateef, Suhaimi Misha, Noreffendy Tamaldin, Mohd Afzanizam Mohd Rosli, and Fadhil Abdulameer Sachit. "A Review: Parameters affecting the PVT collector performance on the thermal, electrical, and overall efficiency of PVT system." Journal of Advanced Research in Fluid Mechanics and Thermal Sciences 60, no. 2 (2019): 191-232.

[37] Parthiban, Anandhi, K. S. Reddy, Bala Pesala, and T. K. Mallick. "Effects of operational and environmental parameters on the performance of a solar photovoltaic-thermal collector." Energy Conversion and Management 205 (2020): 112428. https://doi.org/10.1016/j.enconman.2019.112428

[38] Rosli, Mohd Afzanizam Mohd, Irfan Alias Farhan Latif, Muhammad Zaid Nawam, Mohd Noor Asril Saadun, Hasila Jarimi, Mohd Khairul Anuar Sharif, and Sulaiman Ali. "A Simulation Study on Temperature Uniformity of Photovoltaic Thermal Using Computational Fluid Dynamics." Journal of Advanced Research in Fluid Mechanics and Thermal Sciences 82, no. 1 (2021): 21-38. https://doi.org/10.37934/arfmts.82.1.2138

[39] Jaaz, Ahed Hameed, Husam Abdulrasool Hasan, Kamaruzzaman Sopian, Mohd Hafidz Bin Haji Ruslan, and Saleem Hussain Zaidi. "Design and development of compound parabolic concentrating for photovoltaic solar collector." Renewable and Sustainable Energy Reviews 76 (2017): 1108-1121. https://doi.org/10.1016/i.rser.2017.03.127

[40] Jaaz, Ahed Hameed, Kamaruzzaman Sopian, and Tayser Sumer Gaaz. "Study of the electrical and thermal performances of photovoltaic thermal collector-compound parabolic concentrated." Results in Physics 9 (2018): 500-510. https://doi.org/10.1016/i.rinp.2018.03.004

[41] Proell, M., P. Osgyan, H. Karrer, and C. J. Brabec. "Experimental efficiency of a low concentrating CPC PVT flat plate collector." Solar Energy 147 (2017): 463-469. https://doi.org/10.1016/i.solener.2017.03.055

[42] Bayrak, Fatih, Nidal Abu-Hamdeh, Khaled A. Alnefaie, and Hakan F. Öztop. "A review on exergy analysis of solar electricity production." Renewable and Sustainable Energy Reviews 74 (2017): $755-770$. https://doi.org/10.1016/i.rser.2017.03.012

[43] Yazdanifard, Farideh, Ehsan Ebrahimnia-Bajestan, and Mehran Ameri. "Performance of a parabolic trough concentrating photovoltaic/thermal system: effects of flow regime, design parameters, and using nanofluids." Energy Conversion and Management 148 (2017): 1265-1277. https://doi.org/10.1016/j.enconman.2017.06.075

[44] Adam, Saadelnour Abdueljabbar, Xing Ju, Zheyang Zhang, Mostafa M. Abd El-Samie, and Chao Xu. "Theoretical investigation of different CPVT configurations based on liquid absorption spectral beam filter." Energy 189 (2019): 116259. https://doi.org/10.1016/j.energy.2019.116259 